\title{
КОНКУРЕНТНІ ПЕРЕВАГИ ПІДПРИСМСТВ ПЕРЕРОБНОЇ ГАЛУЗІ В УМОВАХ ЕКОНОМІЧНОЇ КРИЗИ
}

\section{COMPETITIVE ADVANTAGES OF PROCESSING INDUSTRY ENTERPRISES IN THE CONDITIONS OF ECONOMIC CRISIS}

В роботі досліджено підприємства переробної галузі в напрямку їх конкурентних переваг. Надано визначення конкурентних переваг визначними науковиями. Представлено загальні принципи, які дають конкурентні переваги виробникам. Конкурентні переваги мають різні форми прояву, які автором представлено у вигляді класифікаційної структури. Також надано характеристику цим конкурентним перевагам, їх склад і залежність від галузі для підприємств переробної промисловості. Запропоновано конкурентні переваги, які будуть пов'язані головним чином з розвиненістю сировинної бази, технічною перевагою, товарними і технологічними інноваціями, пізнаваністю торгової марки, низькими витратами, територіальним розташуванням.

Ключові слова: конкурентні переваги, переробна галузь, економічні показники, конкуренція, принципи, конкурентоспроможне підприємство, сировинна база, класифікаційна структура.

Постановка проблеми. Формування конкурентних переваг у переробній галузі промисловості - це вирішення проблеми іiі виживання і подальшого розвитку. Особливо це актуально в умовах глобалізації економіки, майбутнього вступу України до Світової організації торгівлі. Інтернаціоналізація економіки, тиск імпорту роблять проблему адаптації та сталого розвитку вітчизняних підприємств однією з першочергових.

Перехід до ринкової економіки викликав поглиблення диспропорцій між продуктивним, фінансовим і торгово-посередницьким капіталом, що позначилося на рівні конкурентоспроможності вітчизняних виробників.

Переробна галузь промисловості є одним із найбільших сегментів української економіки. Її особлива роль визначається значимістю груп продуктів як важливого джерела харчування людини.

Нині в переробній галузі промисловості намітилися суттєві позитивні тенденції. Економічні показники галузі свідчать про стійке зростання виробництва. Для багатьох підприємств переробної галузі промисловості вже не стоїть гостро проблема виживання. В першу чергу, це стосується підприємств-лідерів. Основний напрям розвитку сьогодні - не тільки нарощування обсягів виробництва, а формування конкурентних переваг, причому вищого порядку, і на цій основі досягнення нової якості економічного зростання.

Перед підприємствами переробної галузі промисловості стоїть завдання детального аналізу механізму формування конкурентних переваг, вибору і реалізації ефективних стратегій економічної поведінки. Збільшують свою наукову і практичну затребуваність і потребують глибшого дослідження проблеми міжгалузевої збалансованості переробки та сировинної бази, урахування ризику при обгрунтуванні конкурентних стратегій, ролі інноваційних факторів їх формування. Все це зумовило вибір теми дослідження.

Аналіз останніх досліджень та публікацій. Теоретичні питання конкурентоспроможності та конкурентних переваг підприємств розглядалися в роботах багатьох видатних економістів, зокрема, Е. Діхтль, А. Лайан, Х. Хершген, Х. Швальбе, М. Портера, Ж.-Ж. Ламбена, Ф. Котлера, П. Дойля та ін. На сьогодні дослідженню питань суті та джерел формування конкурентних переваг підприємств присвячені праці П. С. Смоленюка, Л. В. Балабанової, І. З. Должанського, С. Дорогунцова, С. П. Гаврилюка, С. Мочерного, Р. А. Фатхуддінова, О. Зозульова та ін.

Незважаючи на те, що в Україні проблема формування конкурентних переваг підприємницької діяльності стоїть досить гостро, практичні заходи принципового характеру в цьому відношенні потрібно нарощувати. Спираючись на знання, накопичені світовою наукою й практикою, з урахуванням їхнього розумного застосування до специфіки українських умов важливо з'ясувати визначення та роль конкурентних переваг у конкурентній боротьбі та прийнятті управлінських рішень.

Метою статті $\epsilon$ дослідження конкурентних позицій підприємств переробної галузі України та регіональні особливості їх формування. 
Виклад основного матеріалу. В процесі зростаючої глобалізації, вступу до Світової організації торгівлі формування і нарощування конкурентних переваг вищого порядку є неодмінною умовою конкурентоспроможності. Створення і розвиток конкурентоспроможних підприємств, що реалізують конкурентні переваги і базуються на науково-технічних досягненнях, інноваціях на всіх стадіях створення і просування товару, використанні людського капіталу, сучасних інформаційних технологій, можливостях маркетингу, вдосконаленні організаційного управління, дозволить захистити місцевих виробників від експансії світового ринку.

Конкуренція вважається найважливішим фактором успішного функціонування економіки, що спонукає виробників постійно вдосконалювати свій товар і дає споживачам можливість найкращим чином задовольнити свої потреби. Вона так само приводить до появи принципово нових засобів задоволення потреб людини. Відсутність конкуренції загрожує консервацією сформованого на ринку становища і згубно позначається на розвитку економіки. Обмеження конкуренції в ряді країн переслідується законом.

Сенс конкуренції - не в тому, щоб знищити суперника, і не в тому, щоб компанії-виробники виснажували свої сили в боротьбі за споживача. Мета конкуренції - забезпечити ефективний розвиток галузі і оптимальне задоволення потреб цільового ринку.

Конкуренція, безумовно, $є$ важливою силою, що діє на ринку і з якою зіткнеться будь-яке підприємство. Діючи в рамках законодавства, фірми намагаються переконати споживачів купувати їх товар, використовуючи свою перевагу перед конкурентами. Саме ці «переваги» і називаються конкурентними перевагами.

У загальному вигляді, конкурентна перевага - це перевага підприємства в чому-небудь, що відрізняє його від конкурентів і забезпечує йому перевагу на ринку.

В економічній літературі існує безліч визначень поняття «конкурентна перевага». Згідно 3 Г. Л. Азоєвим, конкурентна перевага - це становище фірми на ринку, що дозволяє ій долати сили конкуренції та приваблювати до себе покупців. Основою конкурентної переваги $є$ унікальні активи підприємства чи особлива компетентність у сферах діяльності [1, с. 125].

За М. Портером, конкурентна перевага - перевага, висока компетентність фірми в якій-небудь сфері діяльності або у випуску товару порівняно з конкуруючими фірмами. Фактором конкурентної переваги є конкретний компонент зовнішнього або внутрішнього середовища фірми, за яким вона перевершує конкуруючі фірми.

Ж.-Ж. Ламбен вважає, що конкурентна перевага - це ті характеристики властивості товару або марки, які створюють для фірми певну перевагу над своїми прямими конкурентами.

Ці характеристики можуть бути дуже різними і відноситися як до самого товару, так і до додаткових послуг, які супроводжують базову. Отже, зазначена перевага є відносною порівняно з конкурентом, який займає найкращу позицію на ринку або в системі ринку.

Конкурентна перевага, насамперед, - це здатність підприємства якнайкраще застосувати свої обмежені ресурси, досягаючи більш стійкого і тривалого становища на ринку, ніж конкуренти. Тобто потрібно визначити, куди вигідніше спрямовувати ресурси, які можливості підприємства слід розвивати, щоб забезпечити високий рівень його конкурентоспроможності.

Конкурентні переваги є концентрованим проявом переваги над конкурентами в економічній, технічній, організаційній сферах діяльності підприємства, який можна виміряти економічними показниками (додатковий прибуток, більш високі рентабельність, ринкова частка, обсяг продажів). Необхідно особливо підкреслити, що конкурентну перевагу не можна ототожнювати з потенційними можливостями підприємства. На відміну від можливостей, це факт, який фіксується в результаті реальних i очевидних переваг покупців. Саме тому в практиці бізнесу конкурентні переваги є головною метою і результатом господарської діяльності

Отже, конкурентна перевага - це цінність, якою володіє система, що дає їй перевагу перед конкурентами. Конкурентна перевага забезпечується факторами: матеріальними або віртуальними; зовнішніми і внутрішніми; базисними або другорядними; спрямованими на підвищення якості об'єкта за стадіями його життєвого циклу, як-то: ресурсозбереження, зниження матеріаломісткості, трудомісткості, енергоємності; стратегічними або тактичними; технічними, економічними, організаційними, психологічними, природно-кліматичними; спадковими або штучними (набутими).

Т. Пітері і Б. Уотермен сформулювали загальні принципи які дають конкурентні переваги виробникам $[9$, с. 189$]$ :

- націленість усіх і кожного працівника на дію, на продовження розпочатої справи; 
- близькість підприємства до клієнта;

- створення автономії і творчої атмосфери на підприємстві;

- зростання продуктивності завдяки використанню здібностей людей і їх бажанню працювати;

- демонстрація важливості загальних для підприємства цілей;

- вміння твердо стояти на своєму;

- простота організації, мінімум рівнів управління і службового персоналу;

- вміння бути одночасно м'яким і жорстким, тримати під жорстким контролем найбільш важливі проблеми і передавати підлеглим менш важливі.

Як показує світова практика ринкових відносин, взаємозалежне вирішення цих проблем і використання цих принципів гарантує підвищення конкурентоспроможності підприємств. Головними напрямами забезпечення конкурентної переваги підприємства $є$ : концентрація ресурсів підприємства для попередження дій конкурентів, утримування ініціативи в конкурентній боротьбі, забезпечення ресурсного потенціалу для досягнення поставлених цілей, розробка гнучкої системи планування діяльності фірми на ринку шляхом обгрунтування ефективної стратегії взаємодії з конкурентами.

Конкурентні переваги мають ієрархію і можуть належати:

- до товару;

- до функціональної сфери діяльності (досліджень, виробництва. менеджменту й ін.);

- до підприємства, галузі, економіки країни, суспільства в цілому.

Конкурентні переваги підприємства можуть бути:

- за часом дії: короткострокові та довгострокові;

- за можливістю імітації: імітовані та унікальні.

Залежно від чинників, що визначають конкурентні переваги підприємства, в літературі виділяють таку їх класифікацію: природні і набуті, абсолютні і порівняльні конкурентні переваги (А. Сміт, Д. Ріккардо), внутрішні і зовнішні конкурентні переваги (Р.А. Фатхутдінов), конкурентні переваги вищого і нижчого порядку, тактичні та стратегічні конкурентні переваги (М. Портер).

Конкурентні переваги мають різні форми прояву, які можна зобразити у вигляді класифікаційної структури (рис. 1).

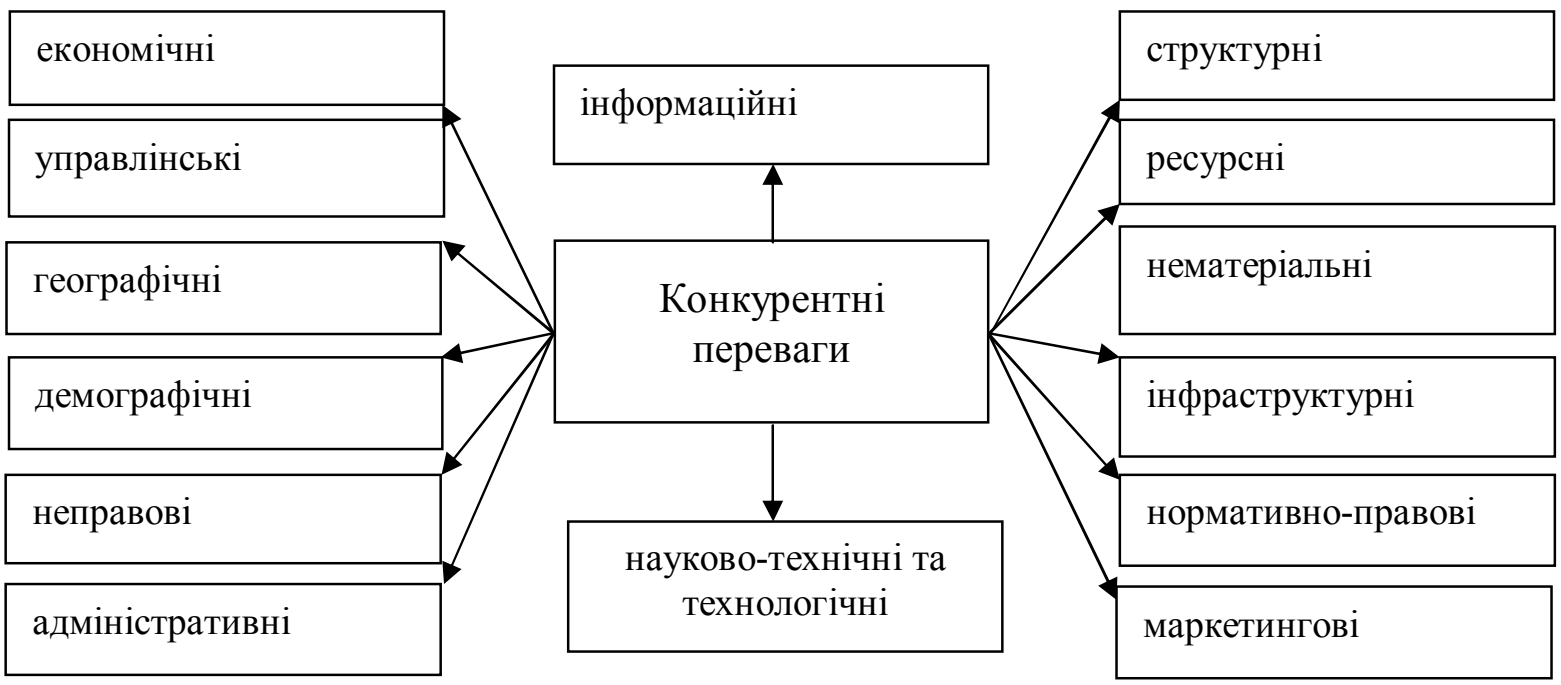

Рис. 1 Види конкурентних переваг підприємства

1. Конкурентні переваги, які грунтуються на економічних факторах, визначаються: кращим загальноекономічним станом ринків, на яких діє підприємство; стимулюючою політикою уряду в сфері обсягів інвестицій, кредитних, податкових і митних ставок; об'єктивними факторами, що стимулюють попит; ефектом масштабу і досвіду; економічним потенціалом підприємства; можливістю вишукування і ефективного використання джерел фінансування.

2. Конкурентні переваги, які грунтуються на нормативно-правових актах, існують внаслідок законів, постанов, особливих привілеїв та інших рішень органів влади і управління (пільги або інші привілеї, надані регіону або окремим підприємствам органами влади і управління, можливості безперешкодного ввезення-вивезення товарів, виняткові права на інтелектуальну власність. 
3. Конкурентні переваги структурного характеру визначаються високим рівнем інтеграції процесу виробництва і можливістю швидкої експансії в незайняті сегменти ринку, витісненням реальних і потенційних конкурентів;

4. Конкурентні переваги ресурсного характеру - це доступ до якісної сировини, інших ресурсів та оптимізація ефективності використання ресурсів.

5. Конкурентні переваги управлінського характеру визначаються кваліфікацією та професіоналізмом менеджерів; аналізом виконання законів організації; функціонуванням системи менеджменту; функціонуванням системи управління якістю в організації.

6. Конкурентні переваги, викликані адміністративними заходами, пов'язані з наявністю обмежень діяльності виробників (постачальників), які не всім вдається подолати (видача патентів і ліцензій, квотування, ускладнений порядок реєстрації підприємств, перешкоди у відведенні земельних ділянок, надання виробничих і службових приміщень тощо).

7. Переваги, які визначаються рівнем розвитку інфраструктури ринку (розвитку необхідних засобів комунікації (транспорту, зв'язку); організованості і відкритості ринків праці, капіталу, інвестиційних товарів і технологій у регіонах; розвитку дистриб'юторської мережі, в тому числі роздрібної, оптової, ф'ючерсної торгівлі; служб з надання консалтингових, інформаційних, лізингових та іншого роду ділових послуг; міжорганізаційної кооперації).

8. Науково-технічні й технологічні конкурентні переваги визначаються високим рівнем розвитку прикладної науки і техніки в галузі.

9. Конкурентні переваги, які визначаються хорошою інформованістю (наявність великого банку даних про продавців, покупців, рекламної діяльності, інформації про інфраструктуру ринку).

10. Конкурентні переваги, що грунтуються на географічних факторах (можливість економічного подолання географічних кордонів ринків (локальних, регіональних, національних, світових), а також вигідне географічне розташування підприємства).

11. Конкурентні переваги, що грунтуються на демографічних факторах, які формуються в результаті демографічних змін у цільовому сегменті ринку і їх позитивного впливу на обсяг і структуру попиту на пропоновану продукцію (послуги), збільшення чисельності цільової групи населення, зміна його вікового складу, міграції населення, а також зміни освітнього та професійного рівня.

12. Маркетингові конкурентні переваги - це лідерство на ринку товарів; ексклюзивність каналів розподілу; ексклюзивність реклами товарів організації; прогнозування політики ціноутворення і ринкової інфраструктури.

13. Нематеріальні конкурентні переваги - назва підприємства, торгові марки, бренд підприємства, його відносини зі споживачами, постачальниками, державою і суспільством.

14. Конкурентні переваги неправового характеру (недобросовісна конкуренція; несумлінне виконання представниками федеральних і місцевих органів влади своїх обов'язків, бюрократизм, невиправдана тяганина з розглядом справ, хабарництво, корупція; кримінальні дії).

Стосовно підприємств переробної галузі промисловості, то для них також характерні вищенаведені конкурентні переваги. Але сучасний рівень розвитку конкуренції на ринку підприємств переробної галузі промисловості характеризується тим, що вони функціонують в умовах агресивного і нестабільного зовнішнього оточення. Трансформація конкурентних спільнот, обумовлена активним входженням на ринок нових учасників, в тому числі й зарубіжних, зростанням і якісним ускладненням потреб споживачів, призводить до постійної зміни конкурентних позицій вітчизняних товаровиробників.

Конкурентоспроможне переробне підприємство повинне не тільки перевершувати конкурентів 3 позиції більш ефективного використання свого внутрішнього потенціалу, але й володіти гнучкою, адаптивною реакцією на зовнішні можливості і загрози.

Склад конкурентних переваг також залежить від галузі. Так, для підприємств переробної галузі промисловості конкурентні переваги будуть пов'язані головним чином з розвиненістю сировинної бази, технічною перевагою, товарними і технологічними інноваціями, пізнаваністю торгової марки, низькими витрати, територіальним розташуванням (рис. 2).

Чим вища сила конкуренції в галузі, тим меншими будуть прибутковість і собівартість товарів, але вищою - інтенсивність і якість товарів.

Як і багато інших галузей, переробна промисловість потребує оновлення матеріальнотехнічної бази, модернізації виробництва шляхом впровадження інноваційних технологій, збільшення обсягів випуску конкурентоспроможної продукції, залучення іноземних інвесторів, налагодження роботи на внутрішньому ринку і освоєння нових зовнішніх ринків збуту вітчизняної продукції. 


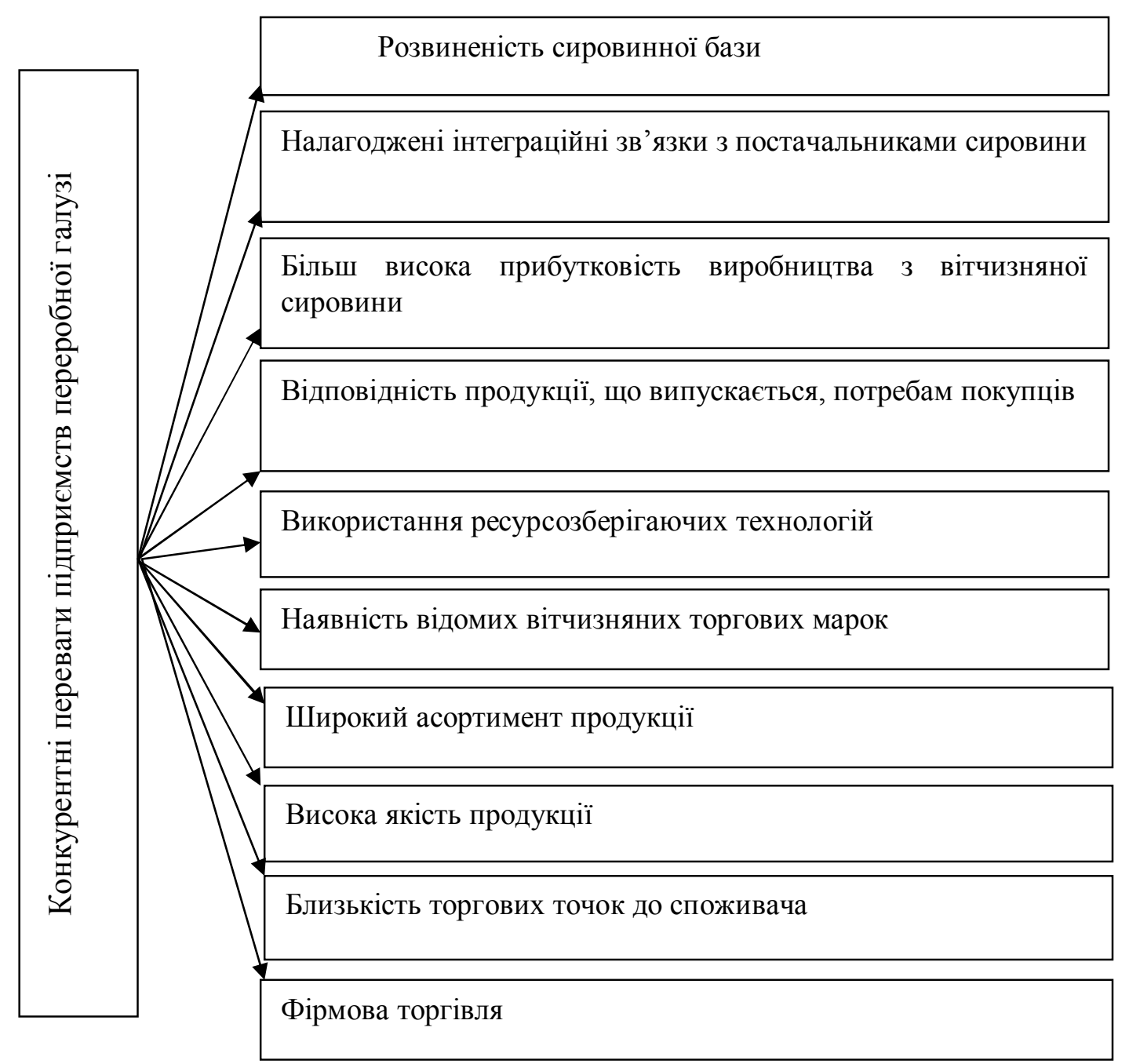

Рис. 2. Конкурентні переваги підприсмств переробної галузі

Завоювання і збереження конкурентних переваг - ключова функція стратегічного управління підприємств переробної галузі. Головна передумова формування стратегічних факторів конкурентної переваги полягає в здатності підприємств виявити і утримати протягом тривалого часу свої переваги як виробника товару порівняно з конкуруючими.

На ринках споживчих товарів, як правило, конкурентні позиції підприємства ототожнюються 3 рівнем марки товару. Оцінювання конкурентних позицій товарних марок здійснюється шляхом зіставлення сильних і слабких сторін власного підприємства і конкурентів.

При дослідженні конкурентоспроможності підприємств переробної галузі промисловості зазвичай виділяють три вимоги, яким мають відповідати чинники конкурентної переваги, щоб вважатися стратегічними: протягом тривалого часу забезпечувати унікальність власної марки порівняно 3 конкуруючими; задовольняти специфічні потреби клієнта, тобто забезпечувати постійну вигоду цільовій групі споживачів; будуватися на специфічних здібностях і ресурсах підприємств, які важко або неможливо імітувати.

Значущих результатів на ринку можна добитися не просто за допомогою ефективної організації виробництва і оптимального використання ресурсів, а завдяки їх адекватному застосуванню. Так, кваліфікація персоналу, організаційна культура стають основою зміцнення позиції товарної марки в свідомості споживача, якщо в результаті їх використання створюється товар, що володіє високими споживчими якостями.

Висновки. Отже, конкурентна перевага підприємства переробної галузі промисловості - це особлива характеристика або деяке особливе сполучення характеристик його ресурсного потенціалу, що забезпечує динамічну підтримку конкурентоспроможності вироблених товарів та послуг. 
Конкуренція змушує впроваджувати у виробництво інноваційні процеси і технології для зменшення витрат на виробництво. Тим самим виробники підвищують якість товару та привертають увагу нових покупців, а отже, й збільшують власні прибутки.

Таким чином, можна зробити висновок, що чим більше підприємства переробної галузі промисловості мають конкурентних переваг перед дійсними і потенційними конкурентами, тим вищими $€$ їх конкурентоспроможність, живучість, ефективність, перспективність.

\section{Список використаних джерел}

1. Азоев Г. Л. Конкурентные преимущества фирмы / Г. Л. Азоев, А. П. Челенков. - М. : Типография «НОВОСТИ», 2000. -255 с.

2. Безсмертний С. Ю. Сутність та класифікація конкурентних переваг підприємства / С. Ю. Безсмертний // Вісник НУ «Львівська політехніка». Менеджмент та підприємництво в Україні: етапи становлення і проблеми розвитку. - 2011. - № 714. - С. 174-179.

3. Войчак А. В. Конкурентні переваги підприємства: сутність і класифікація / А. В. Войчак, Р. В. Камишніков // Маркетинг в Україні. - 2005. - № 2 (30). - С. 50-53.

4. Городня Т. А. Інноваційні чинники формування конкурентних переваг діяльності підприємств / Т. А. Городня, В. В. Бенч // Науковий вісник НЛТУ України. - 2011. - Вип. 21.18. - С. 183-187.

5. Дубинина Н. А. Подходы к формированию конкурентной стратегии предприятия / Н. А. Дубинина // Вестник АГТУ. - 2010. - № 2. - С. 65-71.

6. Загорянська О. Л. Формування конкурентних переваг машинобудівних підприємств в сучасних умовах розвитку / О. Л. Загорянська, О. П. Косенко, П. Г. Перерва // Вісник національного технічного університету «Харківський політехнічний інститут» : зб. наук. праць. - 2012. - № 4. - С. 80-86.

7. Іванов Ю. Б. Конкурентні переваги підприємства: оцінка, формування та розвиток : [монографія] / Ю. Б. Іванов, П. А. Орлов, О. Ю. Іванова. - Х. : ІНЖЕК, 2008. - 352 с.

8. Коляденко С. В Стратегічне управління конкурентоспроможністю підприємств агропромислового комплексу / С. В. Коляденко // Збірник матеріалів Чотирнадцятих річних зборів Всеукр. конгр. вчених економістіваграрників, (м. Київ, 16-17 жовтня 2012 р.). - К. : ННЦ «IAЕ», 2013. - С. 247-250.

9. Конкурентоспроможність підприємства: оцінка рівня та напрями підвищення : [монографія / за заг. ред. О. Г. Янкового]. - Одеса : Атлант, 2013. - 470 c.

10. Кузнецова I. О. Формування стійких конкурентних переваг: концептуальна модель / I. О. Кузнецова // Вiсник соціально-економічних досліджень : зб. наук. праць Одеського державного економічного університету. - Одеса : ОДЕУ, 2010. - № 38. - С. 68-71.

11. Нестеренко С. А. Конкурентоспроможність сільськогосподарських підприємств: управлінський аспект [монографія] / С. А. Нестеренко. - К. : Аграр Медіа Груп, 2013. - 483 с.

12. Рубин Ю. Б. Стратегии и тактики конкурентного поведения / Ю. Б. Рубин // Современная конкуренция. 2007. - № 3. - С. 81-96.

13. Урасова А. А. Формирование устойчивых конкурентных преимуществ: стратегия и бренд / А. А. Урасова // ARS ADMINISTRANDI. - Пермь : Пермский гос. нац. исслед. ун-т, 2012. - № 4. - С. 76-80.

\section{References}

1. Azoev, H. L. and Chelenkov, A. P. (2000), Competitive advantages of a company [Konkurentnye preimushchestva firmy, Tipografiya "NOVOSTY", Moscow, 255 p.

2. Bezsmertnyy, S. Yu. (2011), "Nature and classification of enterprise competitive advantages" ["Sutnist' ta klasyfikatsiya konkurentnykh perevah pidpryyemstva"], Visnyk $N U$ "L'vivs'ka politekhnika". Menedzhment ta pidpryyemnytstvo $v$ Ukrayini: etapy stanovlennya i problemy rozvytku, No 714, pp. 174-179.

3. Voychak, A. V. and Kamyshnikov, R. V. (2005), "Enterprise competitive advantages: nature and classification" ["Konkurentni perevahy pidpryyemstva: sutnist' i klasyfikatsiya"], Marketynh v Ukrayini, No 2 (30), pp. 50-53.

4. Horodnya, T. A. and Bench, V. V. (2011), "Innovation factors of the formation of competitive advantages of enterprises activities" ["Innovatsiyni chynnyky formuvannya konkurentnykh perevah diyal'nosti pidpryyemstv"], Naukovyy visnyk NLTU Ukrayiny, Issue 21.18, pp. 183-187.

5. Dubinina, N. A. (2010), "Approaches to the formation of enterprise competitive strategy" ["Podkhody k formirovaniyu konkurentnoy strategii predpriyatiya"], Vestnik AGTU, No 2, pp. 65-71.

6. Zahoryans'ka, O. L., Kosenko, O. P. and Pererva, P. H. (2012), "The formation of competitive advantages of machine-building enterprises in modern development conditions" ["Formuvannya konkurentnykh perevah mashynobudivnykh pidpryyemstv v suchasnykh umovakh rozvytku"], Visnyk natsional'noho tekhnichnoho universytetu «Kharkivs'kyy politekhnichnyy instytut» : zb. nauk. prats', № 4, pp. 80-86. 
7. Ivanov, Yu. B., Orlov, P. A. and Ivanova, O. Yu. (2008), Enterprise competitive advantages: evaluation, formation and development [Konkurentni perevahy pidpryyemstva: otsinka, formuvannya ta rozvytok], INZhEK, Kharkiv, $352 \mathrm{p}$.

8. Kolyadenko, S. V (2013), "Strategic management by the competitiveness of agricultural complex enterprises" ["Stratehichne upravlinnya konkurentospromozhnistyu pidpryyemstv ahropromyslovoho kompleksu"], Zbirnyk materialiv Chotyrnadtsyatykh richnykh zboriv Vseukr. konhr. vchenykh ekonomistiv-ahrarnykiv, (Kyiv, 1617 zhovtnya 2012), NNTs "IAE", Kyiv, pp. 247-250.

9. Enterprise competitiveness: evaluation of the level and directions of the growth [Konkurentospromozhnist' pidpryyemstva: otsinka rivnya ta napryamy pidvyshchennya] (2013). In: O. H. Yankovyy (ed.), Atlant, Odesa, $470 \mathrm{p}$.

10. Kuznetsova, I. O. (2010), "The formation of steady competitive advantages: conceptual model" ["Formuvannya stiykykh konkurentnykh perevah: kontseptual'na model'"], Visnyk sotsial'no-ekonomichnykh doslidzhen' : zb. nauk. prats' Odes'koho derzhavnoho ekonomichnoho universytetu, ODEU, Odesa, No 38, pp. 68-71.

11. Nesterenko, S. A. (2013), "Competitiveness of agricultural enterprises: management aspect" ["Konkurentospromozhnist' sil's'kohospodars'kykh pidpryyemstv: upravlins'kyy aspekt"], Ahrar Media Hrup, Kyiv, 483 p.

12. Rubin, Yu. B. (2007), "Strategies and tactics of competitive behaviour" ["Strategii i taktiki konkurentnogo povedeniya, Sovremennaya konkurentsyya, No 3, pp. 81-96.

13. Urasova, A. A. (2012), "The formation of steady competitive advantages: strategy and brend" ["Formirovaniye ustoychivykh konkurentnykh preimushchestv: strategiya i brend"], ARS ADMINISTRANDI, Permskiy gos. nats. issled. un-t, Perm', No 4, pp. 76-80.

\section{Bondarenko}

\section{COMPETITIVE ADVANTAGES OF PROCESSING INDUSTRY ENTERPRISES IN THE CONDITIONS OF ECONOMIC CRISIS}

Processing industry enterprises in the direction of their competitive advantages are investigated in this work. Competitive advantages determinations by a number of prominent scientists are provided. The general principles that give competitive advantages to producers are presented. Competitive advantages have different forms that can be presented as a classification structure. Also, the characteristics of these competitive advantages, their composition and dependence on processing industry enterprises are given. Competitive advantages, associated mainly with the development of raw materials base, technological superiority, commodity and technological innovation, brand, low cost, territorial location, are offered.

Thus, competitive advantage of processing industry is a feature or some combination of special characteristics of its resources, providing dynamic support to the competitiveness of manufactured goods and services.

Competition makes to implement innovative processes and technologies in production in order to reduce production costs. Thus, producers increase the quality of the product and both attract new customers and increase their profits.

Keywords: competitive advantages, processing industry, economic performance, competition, principles, competitive enterprise, raw materials, classification structure.

Статтю представляс В. М. Бондаренко, доктор економічних наук, професор, Вінницький торговельноекономічний інститут Київського національного торговельно-економічного університету. 